\title{
Water Quality Parameters: A Case Study of Karnafully River Chittagong, Bangladesh
}

\section{Iqbal Sarwar,*a Ahmad Kamruzzaman Majumder ${ }^{\mathrm{b}}$ and M. Nurul Islam ${ }^{\mathrm{c}}$}

${ }^{a}$ Department of Geography and Environmental Studies, University of Chittagong, Bangladesh, ${ }^{b}$ Department of Environmental Science and Engineering, Kathmandu University, P.O. Box 6250, Kathmandu, Nepal, ${ }^{c}$ Department of Geography \& Environment, Jahangirnagar University, Savar, Bangladesh

\begin{abstract}
The river Karnafully is one of the Himalayan River originating from the Lushai Hills in India. The catchments of the Karnafully and its allied streams cover 5,500 (14,000 sq km) square miles. Water samples were collected from Karnafully River along different points and analyzed for various physiochemical parameters during winter. Effects of industrial wastes, municipality sewage and agricultural runoff on the river water were investigated. The study was conducted between the Kaloorghat Bridge and Patenga estuary including Chittagong port. This is the most polluted area due to the presence of many chemical fertilizers, iron, leather and pharmaceutical industries. All these industries discharge their untreated toxic waste water directly into the river Karnafully. The study involved determination of physical and chemical parameters of surface water at different points. The mean values of water temperature, total suspended solids (TSS), total dissolved solids (TDS), total solids (TS), turbidity, dissolved oxygen (DO), bio-chemical oxygen demand (BOD), chemical oxygen demand (COD), pH, electric conductivity and total alkalinity were $23^{\circ} \mathrm{C}, 365.87 \mathrm{mg} / \mathrm{L}, 8018.8,8518.33 \mathrm{mg} / \mathrm{L}, 31.54 \mathrm{FTU}, 1.55 \mathrm{mg} / \mathrm{L}, 6.65 \mathrm{mg} / \mathrm{L}, 13961$ s/cm, $247.47 \mathrm{mg} / \mathrm{L}, 560.27 \mathrm{mg} / \mathrm{L}$ and $4.8 \mathrm{mg} / \mathrm{L}$ respectively.
\end{abstract}

Key words: Physiochemical parameters, Winter season, Monsoon season, Dissolved oxygen, Biological oxygen demand.

\section{Introduction}

Water is a universal symbol of life. The reality of water resources in Bangladesh, however, is a cause for grave concern. Both the quantity and the quality of surface and ground water supplies are already uneven, and the incidence of pollution and of scarcity is on the rise. Water is essential for all living beings, and man is no exemption. So most of the human civilization has developed on the banks of rivers, lakes or seas. Today, nearly 40 percent of the world's food supply is grown under irrigation, and a wide variety of industrial processes depends on water (BCAS, 2000). Bangladesh is a land of rivers. Around 230 rivers flow through the country including 53 international rivers. Urbanization is the main reason of pollution for these rivers and other water bodies (DoE, 2001). Several studies (DoE, 1993; Hossain, 2001) showed that surface water quality of the rivers of the country is highly polluting day by day. River Karnafully is the largest and an important river in Chittagong and the Chittagong Hill Tracts, originating from South Lushai Hills, a lofty range of Hills of Assam in India at Latitude $23^{\circ} 53^{/} \mathrm{N}$ and Longitude $92^{\circ} 27^{/}$E. The Karnafully river enters into region Chittagong in the west and south?west directions and finally falls after a course of $180 \mathrm{~km}$, into the Bay of Bengal in $22^{\circ} 14^{/} \mathrm{N}$ and $91^{\circ} 47^{/} \mathrm{E}$ at Patenga, leaving the city of Chittagong on its right bank, about $16 \mathrm{~km}$ away from the outlet. Before that, it travels through mountainous wilderness making a narrow loop at Rangamati and then follows a zigzag course forming two other prominent loops, the Dhuliachhari and the Kaptai. The hydroelectric dam is situated just before the entrance of the river into the Kaptai loop. River Karnafully that facilitated the initiation with escalation of the dwelling places as well as industrialization along its shores. During its flow it promotes industrial, agriculture, fishing, household and navigational infrastructure. It is now faced with terrible deterioration of natural water characteristics (Hossain and Khan, 2002). In Chittagong the Karnafully made most significant change in its course from Kalurghat downwards. The change has been taking place for more than a century. Formerly, the river had a western and southwestern course from Kalurghat followed by Sampanghata, Suloop Bahar, Kapashgola, Chowk Bazar, Roomghata, Ghat

\footnotetext{
* Corresponding author: E-mail: iqbalsrwr@yahoo.com
} 
Farhadbeg, Boxirhat, Patharghata on its right bank. But gradually it receded to the left throwing up vast and extensive alluvial lands along its right bank, now known as Char Bakalia, Chandgaon, Char Chaktai, etc. The above ghats and bazars which once dotted the right bank of the Karnafully along the eastern limits of the town are now important localities in and outside the municipality, far away from the present course of the river. For centuries it has shaped the lives of the people living along its banks. With marked rise in population and consequent increase in irrigation and a flurry of industries, the demand for pure natural water is increasing. Incongruously, growing urban population is producing greater loads of urban waste, and the industries that need so much clean water are throwing out their effluents directly or indirectly into Karnafully (Majid, et. al., 1999). Industrial wastes are known to adversely affect natural life by direct toxic action or indirectly through qualitative alterations in the character of the water as well as that of the stream bed (Ahmed, 2000). Urban wastes, on the other hand, cause organic enhancement and spread pathogens of devastating and serious diseases. The study was conducted between the Kaloorghat Bridge and Patenga estuary including Chittagong port. This area is most polluted due to the presence of chemical fertilizer, iron, leather and pharmaceutical industries. All these industries discharge their untreated toxic waste water directly into the river Karnafully. Thus the study involved determination of physical and chemical parameters of surface water at different points. The objectives of the study are to assess the present water quality, through analysis of some selected water quality parameters like color, odor, temperature, pH, TSS, TDS, TS, BOD, COD, DO, turbidity, EC and salinity etc. and to compare the results with the international and Bangladeshi standards.

\section{Materials and Methods}

Water samples were collected from the Karnafully River during dry seasons in January 2003 and later on in January 2008, and tested for physical qualities and chemical contents. 1.5 liter polypropylene bottles were used for water sample collection. Prior to sample collection, all bottles were washed with dilute acid followed by distilled water and were dried in an oven. Before taking final water samples, the bottles were rinsed three times with the water to be collected. The sample bottles were labeled with date and sampling source. Fifteen sampling points were selected. Sampling locations are shown in Fig. 1. Sampling conditions are illustrated in Table I. Standard procedures were used to analyze the physic-chemical parameters of the water sample. Visual inspection for color, smelling for odor, thermometer (Graduated $0^{\circ} \mathrm{C}$ to $100^{\circ} \mathrm{C}$ ) for temperature, gravimetric method for TSS and TS, Dissolved Oxygen meter (HANNA instruments: H 19143) for DO, single electrode $\mathrm{pH}$ meter (Jenway pH meter, model no. 3305) for pH, EC meter (HANNA instruments: H 19143) for electrical conductivity, and TDS salinity meter (HANNA instruments: $H$ 19143) for salinity and HANNA C-114 turbidity meter for turbidity, 5Day BOD test for BOD, closed reflux titrimetric method for the determination of COD were used.

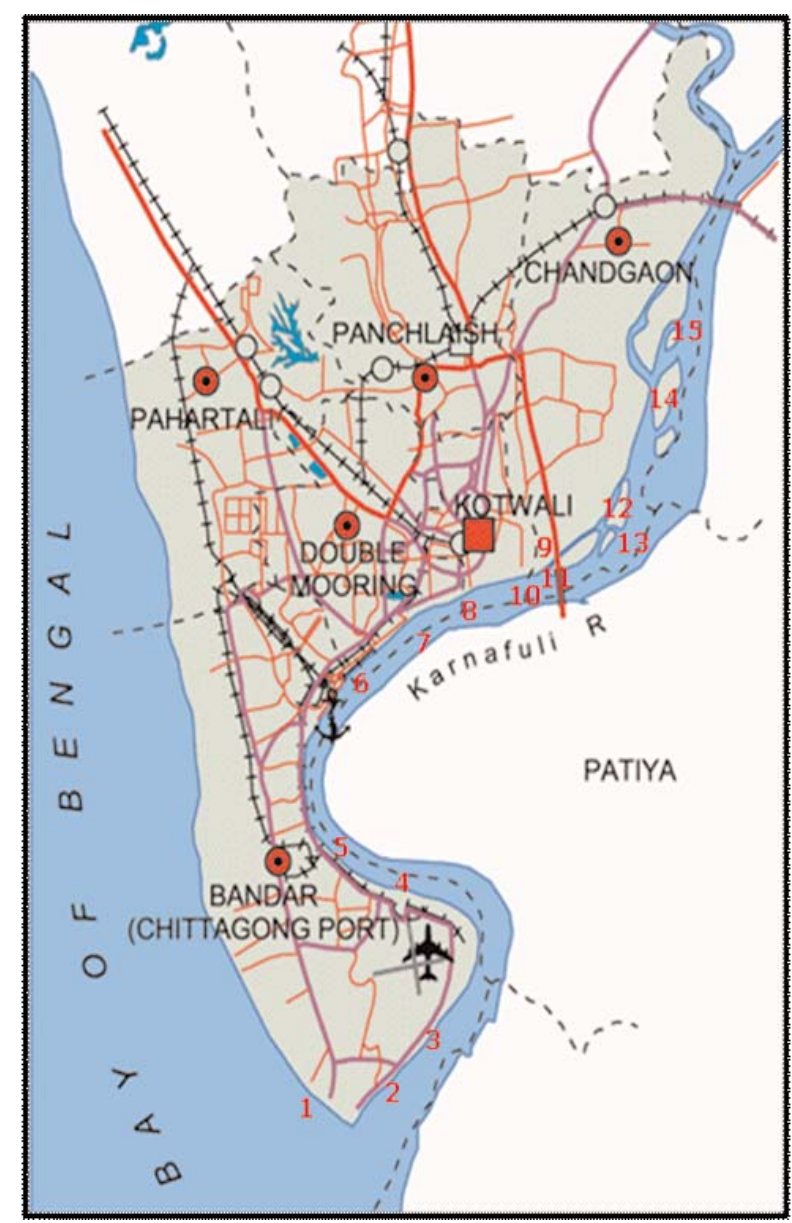

Fig. 1. Study area and sampliin points

\section{Results and Discusion}

Water samples were collected from the Karnafully River during winter seasons and tested for physical and chemical parameters. Fifteen sampling points were selected. The important water quality parameters, such as color, odor, temperature, pH, TSS, TDS, TS, BOD, COD, DO, turbidity, EC and salinity etc. were analyzed. 
Table I. The sampling locations and its tidal condition

\begin{tabular}{l|l|l|l}
\hline S.No & Sampling sites / sources & Sample ID & Condition \\
\hline 1 & Patenga Sea Beach & S-1 & High tide \\
2 & Patenga Nevay Academy & S-2 & High tide \\
3 & Nevay Academy Jetty & S-3 & High tide \\
4 & 15 no ghat, opposite of the KAFCO & S-4 & High tide \\
5 & Dry Dock & S-5 & High tide \\
6 & Shipping Corporation & S-6 & High tide \\
7 & Chaktai New Bridge & S-7 & High tide \\
8 & Karnafully River in front of Chaktai Khal & S-8 & High tide \\
9 & Chaktai Khal (Chawkbazar) & S-9 & High tide \\
10 & Firingibazar Khal (at outfall to Karnafully River) & S-10 & Low tide \\
11 & Firingibazar Khal (Up stream) & S-11 & Low tide \\
12 & Monohar Khal (Low tide starting, east of Sadarghat) & S-12 & High tide \\
13 & Monohar Khal (at outfall to Karnafully River) & S-13 & High tide \\
14 & Mazhirghat (Main drain) & S-14 & Low tide \\
15 & Mazhirghat (Outfall to Karnafully River) & Low tide \\
\hline
\end{tabular}

\section{Color, odor and temperature}

The river water should be colorless. As show in the Table II, 7 samples were nearly colorless, 1 muddy, 4 turbid color, 2 light green and 1 oily and black color. The observation showed that the near the estuary the better was the acceptability in being colorless. The river water should be odorless. As shown in the Table II, 8 water samples were odorless, 1 pungent, 4 high by pungent, 2 shortly pungent. The observation showed that the near the estuary the better was the acceptability in being odorless. In the case of temperature, the standard for sustaining aquatic life is $20-30\left({ }^{\circ} \mathrm{C}\right)$ and as it was winter the entire sample complies with the national standard as the sample were collected during the winter.

\section{TSS, TDS and TS}

Bangladesh Standard for TSS in terms of inland surface water is $150 \mathrm{mg} / \mathrm{L}$. The mean total suspended solids concentrations in Karnafully river was found to be $365 \mathrm{mg} / \mathrm{L}$ which ranges from 120 to $590 \mathrm{mg} / \mathrm{L}$ as stated in Table II. In case of TDS Bangladesh Standard in terms of inland surface water is $1000 \mathrm{mg} / \mathrm{L}$. The mean total dissolved solids concentrations in Karnafully river was found to be $8018 \mathrm{mg} / \mathrm{L}$ which is ranges from 292 to $18530 \mathrm{mg} / \mathrm{L}$ as stated in Table II. The mean total solids concentrations in Karnafully river was found to be $8518 \mathrm{mg} / \mathrm{L}$ which is ranges from 472 to 19210 $\mathrm{mg} / \mathrm{L}$ as stated in Table II. Higher values of total solids may be due to the presence of silt and clay particles in the river water.

\section{DO, BOD and COD}

In the case of dissolve oxygen (DO), standard for sustaining aquatic life is $4 \mathrm{mg} / \mathrm{L}$, whereas for drinking purposes it is 6 $\mathrm{mg} / \mathrm{L}$. DO value for Karnafully river, along our particular reach lies in between $0.10 \mathrm{mg} / \mathrm{L}$ to $3 \mathrm{mg} / \mathrm{L}$ in winter as shown in Table II. While in the case of biochemical oxygen demand (BOD), standard for drinking purpose is $0.2 \mathrm{mg} / \mathrm{L}$, sewage effluent $20 \mathrm{mg} / \mathrm{L}$ which is exceeded to a great extent as shown by the mean values of $247 \mathrm{mg} / \mathrm{L}$ in Table II. Chemical oxygen demand (COD) is another important parameter of water quality assessment. A standard for drinking purposes is $4 \mathrm{mg} / \mathrm{L}$, which are not acceptable in-terms of Karnafully river water sample analyzed value as stated in Table II.

\section{pH, turbidity, EC and salinity}

$\mathrm{pH}$ is the indicator of acidic or alkaline condition of water status. The standard for any purpose in-terms of $\mathrm{pH}$ is 6.58.5; in that respect the value of Karnafully River water lies between 6.2 to 7.0. Table II indicates slightly acidic water. The mean turbidity of Karnafully River was found 31 FTU, ranging from 14 to $50.1 \mathrm{FTU}$. The mean value of electrical conductivity (EC) of Karnafully River was found to be 13,961 ranging from 552 to $31340 \mu \mathrm{s} / \mathrm{cm}$, whereas Bangladesh Standard for EC in terms of inland surface water is $1200 \mu \mathrm{s} / \mathrm{cm}$. The mean salinity of Karnafully River was found $4.8 \mathrm{mg} / \mathrm{L}$ with a range from 0.4 to $9.2 \mathrm{mg} / \mathrm{L}$. 
Table II. Physical and chemical parameters of Karnafully river water

\begin{tabular}{l|l|l|l|l|l|l|l|l|l|l|l|l|l}
\hline $\begin{array}{l}\text { Samp- } \\
\text { le id }\end{array}$ & \multicolumn{1}{|c|}{ Color } & \multicolumn{1}{|c|}{ Odor } & $\begin{array}{l}\text { Tem. } \\
\left({ }^{\circ} \mathrm{C}\right)\end{array}$ & $\begin{array}{c}\text { TSS } \\
(\mathrm{mg} / \mathrm{L})\end{array}$ & $\begin{array}{c}\text { TDS } \\
(\mathrm{mg} / \mathrm{L})\end{array}$ & $\begin{array}{c}\text { TS } \\
(\mathrm{mg} / \mathrm{L})\end{array}$ & $\begin{array}{l}\text { Turb } \\
(\mathrm{FTU})\end{array}$ & $\begin{array}{c}\text { DO } \\
(\mathrm{mg} / \mathrm{L})\end{array}$ & pH & $\begin{array}{c}\text { EC } \\
(\mu \mathrm{s} / \mathrm{cm})\end{array}$ & $\begin{array}{l}\text { BOD } \\
(\mathrm{mg} / \mathrm{L})\end{array}$ & $\begin{array}{l}\text { COD } \\
(\mathrm{mg} / \mathrm{L})\end{array}$ & $\begin{array}{c}\text { Salinity } \\
(\mathrm{mg} / \mathrm{L})\end{array}$ \\
\hline S-1 & Nearly colorless & Odorless & 21 & 590 & 13200 & 13990 & 42.00 & 3.0 & 7.0 & 19920 & 163 & 390 & 6.20 \\
S-2 & Nearly colorless & Odorless & 21 & 560 & 17500 & 18300 & 50.10 & 2.6 & 6.9 & 31340 & 178 & 380 & 6.50 \\
S-3 & Nearly colorless & Odorless & 22 & 610 & 16100 & 16850 & 49.45 & 2.7 & 6.9 & 29900 & 195 & 420 & 9.20 \\
S-4 & Nearly colorless & Odorless & 23 & 513 & 18530 & 19210 & 48.23 & 2.9 & 7.0 & 31300 & 160 & 350 & 7.00 \\
S-5 & Nearly colorless & Odorless & 23.5 & 360 & 15000 & 15490 & 38.54 & 2.5 & 6.9 & 29200 & 195 & 423 & 9.90 \\
S-6 & Nearly colorless & Odorless & 23.5 & 490 & 12590 & 13193 & 45.00 & 2.3 & 6.8 & 20700 & 200 & 425 & 6.70 \\
S-7 & Muddy & Pungent & 22 & 480 & 510 & 1120 & 40.50 & 0.70 & 6.7 & 1080 & 290 & 635 & 0.40 \\
S-8 & Turbid color & High pungent & 22.5 & 190 & 421 & 695 & 16.20 & 0.20 & 6.6 & 820 & 397 & 865 & 0.40 \\
S-9 & Turbid color & High pungent & 23 & 120 & 292 & 472 & 14.00 & 2.10 & 6.6 & 552 & 198 & 510 & 1.50 \\
S-10 & Light green & High pungent & 24 & 230 & 999 & 1320 & 19.71 & 0.35 & 6.4 & 1806 & 370 & 755 & 5.20 \\
S-11 & Oily \& Black & High pungent & 24.5 & 380 & 6920 & 7441 & 23.33 & 0.65 & 6.2 & 11570 & 285 & 623 & 5.10 \\
S-12 & Turbid color & Odorless & 24 & 175 & 910 & 1167 & 18.45 & 0.40 & 6.4 & 1712 & 273 & 600 & 1.40 \\
S-13 & Nearly colorless & Odorless & 24 & 305 & 7510 & 7932 & 22.00 & 1.50 & 6.5 & 12880 & 243 & 590 & 5.10 \\
S-14 & Light green & Shortly pungent & 23.5 & 210 & 3500 & 3910 & 19.50 & 0.10 & 6.4 & 6190 & 310 & 743 & 2.70 \\
S-15 & Turbid color & Shortly pungent & 23.5 & 275 & 6300 & 6685 & 26.10 & 1.20 & 6.5 & 10450 & 255 & 695 & 4.70 \\
BD & Colorless & Odorless & $20-30$ & 150 & 2100 & - & - & $4.5-8$ & $6-9$ & 1200 & 50 & 200 & - \\
Stand. & & & & & & & & & & & & & \\
\hline
\end{tabular}

The analysis shows that, the water is certainly unfit for drinking purposes without any form of treatment recommended by EU (Claes, 1997; EC, 1986; Bangladesh Gazette, 1997) It still could be considered quite acceptable for various other surface water usage purposes. But the concern that, once a trend in pollution sets in, it generally continues to deteriorate. So years after, serious water quality deterioration

Table III. The location of the water pollution responsible industries

\begin{tabular}{l|c}
\hline Location & Numbers \\
\hline Kaloorghat & 98 \\
Mohra & 85 \\
Chandraghona & 10 \\
Chaktai & 76 \\
Sadarghat & 71 \\
Firingibazar & 60 \\
Fisheryghat & 69 \\
Dry-dock & 89 \\
Katgore & 40 \\
Jaldia & 30 \\
Gohira & 20 \\
Port & 65 \\
\hline Total & 713 \\
\hline
\end{tabular}

Source: Field survey, 2008 could take place. However, there could be gross differences in the test results of some samples at different laboratories in the country, which could limit the use of these data for sen-

Table IV. The type and number of industries close to Karnafully

\begin{tabular}{ll|c}
\hline Sl. No. & Industry & Number \\
\hline 1. & Tannery & 11 \\
2. & Textile & 26 \\
3. & Oil refinery & 01 \\
4. & T.S.P. plant & 01 \\
5. & Urea plant & 02 \\
6. & D.D.T. plant & 01 \\
7. & Chemical industry & 02 \\
8. & Fish processing plant & 20 \\
9. & Asphalt bitumen plant & 01 \\
10. & Steel Mill & 01 \\
11. & Paper and rayon mill & 01 \\
12. & Soft drinks industry & 03 \\
13. & Cement factory & 03 \\
14. & Soap and detergent & 02 \\
15. & Insect killer production plant & 02 \\
16. & Paint and X-ray production unit & 04 \\
17. & Others industry & 75 \\
\hline
\end{tabular}

Source: Field survey, 2008 
sitive policy issues. The differences might be attributed to the approach adopted by laboratories in sample preservation, quality of chemicals used, testing method applied or qualification or expertise of the technicians or test performers. A field survey under the present study found that, from Kaloorghat to the Chittagong Port around 713 industries directly or indirectly throwing their untreated waste or wastewater in Karnafully River. Out of that around 156 are situated very close to the Karnafully. List of such industrial locations and type of industries are noted in Table III and IV respectively.

\section{Conclusion}

Karnafully is an important river of Bangladesh. It is feeding the city in many ways and plays an important role in the communication system of the whole region. Like other city belts, river Karnafully is losing its water quality day by day. At present the river is under severe pollution threat. The chemical analysis of the water samples show the water parameters have already exceede their tolerance limits. Still there is time to control the pollution of the Karnafully. To this end research and monitoring of the water flow in the Karnafully must continue. People should be aware of the possible threats on water pollution in the river.

\section{Acknowledgement}

The authors are thankful to Professor Dr. M. Shahidul Islam and Professor Shafique Haider Chowdhury for valuable advice,and discussion. The authors express thanks to the authority of DoE, Chittagong, specially Junior Chemist Md. Ashadul Hoque, and authority of COSED specially to the Mr. Jabber and Mr. Kabir. Very special thanks to Shohid, Regan, Mahmood, Rana, Tapas and Shohag for their help during sampling and land-use survey.

\section{References}

Ahmed A.U. and Reazuddin, M. (2000). Industrial pollution of water systems in Bangladesh, In Rahman, A. A., Huq, S. and Conway, G. R. (ed). Environmental system of surface water systems of Bangladesh, University Press Limited, Dhaka, Bangladesh pp 175-178.
BCAS (2000) Pollution Study, Management of Aquatic Ecosystem through Community Husbandry (MACH) (Dhaka, Bangladesh).

Bangladesh Gazzette. (1997) Government of People's Republic of Bangladesh.

Claes M. (1997) Comparison Study on river quality, Sci. Tot. Env., 207, pp 141-148.

DoE (1993) Annual Report, Department of Environment, Dhaka, Bangladesh, pp - 25.

DoE. (1997) Environmental Quality Standard for Bangladesh, Ministry of Environment and Forestry, Department of Environment, Dhaka, Bangladesh.

DoE. (2001) The General over view of pollution status of Rivers of Bangladesh, Department of Environment, Dhaka, Bangladesh.

EC. (1986) Guidelines for drinking water quality.

Hossain and Khanb Y. S. (2002) Paper entitled 'An environmental assessment of metal accumulation in the Karnafully estuary, Bangladesh' presented at APN/ SASCOM/LOICZ Regional Workshop, Negombo, Sri Lanka. 8-11 Dec, 2002.

Hossain A. (2001) Evaluation of surface water quality: A case study on Surma River, B.Sc. Engineering thesis, Civil and Environmental Engineering Department, Shahjalal University, Sylhet, Bangladesh.

Majid M. A. and Sharma S. K. (1999). A study of the water quality parameter of the Karnafully River, J. Ban. Chem. Soc., 12(1): 17-24.

Received : January 01, 2009;

Accepted : September 10, 2009 